\title{
The Effect of Difference Temperature on Cortisol, Glucose and Glycogen level of Uceng Fish (Nemacheilus fasciatus)
}

\author{
Harun Wijaya ${ }^{1 *}$, Maheno Sri Widodo ${ }^{2}$, Agoes Soeprijanto ${ }^{2}$ \\ ${ }^{1}$ Master Program of Aquaculture, Faculty of Fisheries and Marine Science, University of Brawijaya, Malang, \\ Indonesia \\ ${ }^{2}$ Department of Aquaculture, Faculty of Fisheries and Marine Science, University of Brawijaya, Malang, Indonesia
}

\begin{abstract}
Nemacheilus is one of the genera of freshwater fish. The existence of Uceng fish (Nemacheilus fasciatus) in public waters is increasingly rare. Changes in water temperature in the maintenance medium will affect the physiological processes of fish. The purpose of this study was to analyze physiological responses (blood glucose levels, cortisol, and glycogen hormones) of Uceng Fish ( $N$. fasciatus) which were incubated at different temperatures and find out the initial time of Uceng fish adaptation to its new environment. Total of 200 fish were collected from wild catches in the Lekso River, Blitar. Fish tissue collection was carried out to test the profile of glucose, cortisol, and glycogen. The research activities at this stage were carried out by raising the Uceng fish from nature to a cultivation container in an aquarium of size $50 \times 30 \times 30 \mathrm{~cm}$ that given the different temperatures $\left(20^{\circ} \mathrm{C}, 24^{\circ} \mathrm{C}, 28^{\circ} \mathrm{C}\right.$ and $\left.32^{\circ} \mathrm{C}\right)$, and each aquarium is filled with 10 Uceng fish and will be kept for 14 days. ELISA method was used to quantify the parameter. The result of this study showed highest peak of cortisol levels and blood glucose levels was achieved in the treatment of $24^{\circ} \mathrm{C}$ on the $10^{\text {th }}$ day and the lowest in the treatment temperature of $28^{\circ} \mathrm{C}$ on the $6^{\text {th }}$ day. The highest glycogen peak was reached at $32^{\circ} \mathrm{C}$ on day 10 and the lowest peak was reached at $28^{\circ} \mathrm{C}$ on day 2 . We conclude that temperature affects the physiological response (cortisol, blood glucose, and glycogen) of Uceng fish ( $N$. fasciatus). High levels of cortisol and blood glucose indicate stressful fish.
\end{abstract}

Keywords: Fish, Nemacheilus fasciatus, Physiological, Temperature, Uceng.

\section{INTRODUCTION}

Nemacheilus is one of the genera of freshwater fish, all of which are endemic in Asia. Genus Nemacheilus consists of 33 species, estimated 18 species of which are found in Indonesia, i.e. Eight species on the island of Sumatra, two species on the island of Java and eight species in Borneo [1]. However, the number of species from the genus Nemacheilus spread throughout Indonesia is still uncertain, due to the lack of collection and extensive and comprehensive taxonomic examination of these fish groups [2].

In Indonesia, Uceng fish ( $N$. fasciatus) is a specific type of local fish that has a high economic value, these fish are usually sold in processed form in the form of fried flour at a price of IDR 200.000 - IDR 300.000 per kilogram; this determination is the main potential of cultivation [3]. Uceng fish is also sold as an ornamental fish commodity. The overfishing of these fish in natural waters environment without regard to the aspects of sustainability causing this fish to be threatened with extinction [4].

\footnotetext{
* Correspondence address: Harun Wijaya

Email : harunwijaya1993@gmail.com

Address : Dept. Aquaculture, University of Brawijaya, Veteran Malang, Malang 65145.
}

Until now, there is not much information that supports the domestication of Uceng fish, especially for aspects of cultivation. In supporting the domestication of uceng fish, one aspect that must be studied well is the ability of fish to adapt in the ex-situ environment. Especially for water temperature. Changes in water temperature in the cultivation medium will affect the physiological processes of fish [5]. As a result of significant temperature changes, causing fish difficulty in the acclimatization process, which will cause fish stress that can increase the secretion of catecholamines and cortisol. Both hormones at high levels negatively affect the fish's immune system, because increased cortisol in plasma will inhibit the formation of interleukins I and II [6]. It will also affect fish activity and even death due to failure in response to changes in its new environment [7]. Changes in environmental temperature will also have a direct effect on the metabolic process. Therefore, temperature changes will affect the high demand for blood glucose supply for thermogenesis [8].

The purpose of this study was to analyze physiological responses (blood glucose levels, cortisol, and glycogen hormones) Uceng Fish ( $N$. fasciatus) which were incubated at different temperatures and find out the initial time of Uceng fish adaptation to its new environment. 


\section{MATERIALS AND METHODS}

This research was conducted from March to April 2018. For fish rearing activities carried out at the Fish Cultivation Laboratory, Faculty of Fisheries and Marine Sciences, Brawijaya University and blood glucose test, cortisol and glycogen hormones were carried out at FAAL Laboratory, Faculty of Medicine, Brawijaya University.

The test animals used were Uceng fish ( $N$. fasciatus) obtained from wild catches in the Lekso River, Blitar Regency. The experimental design in this study uses a Completely Randomized Design (CRD) which is temperature with values of $20^{\circ} \mathrm{C}, 24^{\circ} \mathrm{C}, 28^{\circ} \mathrm{C}$ and $32^{\circ} \mathrm{C}$. Fish that are raised for about 14 days.

\section{Data Collection \\ The Fish Test}

Total of 200 fishes was collected from wild catches in the Lekso River, Blitar Regency. The research sample from three fishes as control and the rest will be maintained in an aquarium container with a treatment temperature. Each aquarium contains 15 Uceng fishes.

\section{Fish Tissue Collection}

Fish tissue collection is carried out to test the profile of blood glucose, cortisol, and glycogen. Fish tissue collection method based on Guest et al. [9].

\section{Treatment}

The research activities at this stage were carried out by collecting the Uceng fish from nature to a maintenance container in an aquarium of size $50 \times 30 \times 30 \mathrm{~cm}$ that given the different temperatures modified from Syawal and Ikhwan research [10] $\left(20^{\circ} \mathrm{C}, 24^{\circ} \mathrm{C}, 28^{\circ} \mathrm{C}\right.$, and $\left.32^{\circ} \mathrm{C}\right)$ each aquarium is filled with 10 fishes and will be kept for 14 days. The aquarium is aerated to supply oxygen and is equipped with modified artificial currents with the help of a water pump. Every two days a sampling of a fish is sampled for testing its physiological profile (blood glucose, cortisol, and glycogen).

\section{Calculation of Cortisol Levels}

Calculation of cortisol hormone levels was measured using method based on VelascoSantamaría et al. [11].

\section{Calculation of Blood Glucose Levels}

Calculation of blood glucose levels was based on Syawal et al [10] method.

\section{Calculation of Glycogen Levels}

Calculation of glycogen levels is using the method based on Suarsana et al. [12]. The calcu- lation of glycogen in the fish meat is calculated by Elabscience formula [13].

\section{Data Analysis}

Data retrieval techniques are carried out by direct observation, by observing directly the observed subject. The data obtained from the research were analyzed statistically using ANOVA (Analysis of Variance) according to the completely randomized design (CRD). Furthermore, LSD (Least Significance Different) test was carried out. The LSD test was carried out if the test results showed the $F$ value was significantly different or very real different, to determine the treatment that gave the best response at $5 \%$ and $1 \%$ confidence intervals [8]. Then proceed with regression tests and orthogonal polynomial calculations. Furthermore, the overall data obtained from the observations and calculations are analyzed and the results are recorded.

\section{RESULTS AND DISCUSSION Cortisol}

Base on Figure 1, on temperature treatment $20^{\circ} \mathrm{C}$, changes in cortisol levels continued to increase until reaching the highest peak on the $12^{\text {th }}$ day of $239.83 \mathrm{ng} \cdot \mathrm{mL}^{-1}$ then decreased to $228.5 \mathrm{ng} \cdot \mathrm{mL}^{-1}$ on the $14^{\text {th }}$ day. At temperature treatment $24^{\circ} \mathrm{C}$, Cortisol increased to the highest point on day 10 , which was $192.5 \mathrm{ng} \cdot \mathrm{mL}^{-1}$ then continued to decline until the $14^{\text {th }}$ day of 169.83 ng. $\mathrm{mL}^{-1}$. Temperature treatment $28^{\circ} \mathrm{C}$ has almost the same results as temperature treatment $24^{\circ} \mathrm{C}$ namely, cortisol levels continued to increase from the first day of maintenance to reach the highest peak on the $10^{\text {th }}$ day, which was 193.66 ng. $\mathrm{mL}^{-1}$, then there was a decrease until the $14^{\text {th }}$ day which was $187.33 \mathrm{ng} \cdot \mathrm{mL}^{-1}$. However, at temperature treatment $32^{\circ} \mathrm{C}$, cortisol levels continue to increase until the $14^{\text {th }}$ day is 267.83 ng. $\mathrm{mL}^{-1}$.

Changes in cortisol levels in plasma, often used as the main indicator of stress, while the second indicator is an increase in glucose levels [14]. The results of this study, at maintenance temperatures $20^{\circ} \mathrm{C}, 24^{\circ} \mathrm{C}$, and $28^{\circ} \mathrm{C}$ similar to the results of research which state that fish are kept for 14 days, cortisol levels continue to increase at each maintenance temperature [14]. However, at maintenance temperatures $32^{\circ} \mathrm{C}$, Cortisol levels continue to increase, presumably, the displacement of the Uceng fish habitat from natural waters to a maintenance container in the laboratory causes prolonged stress. 


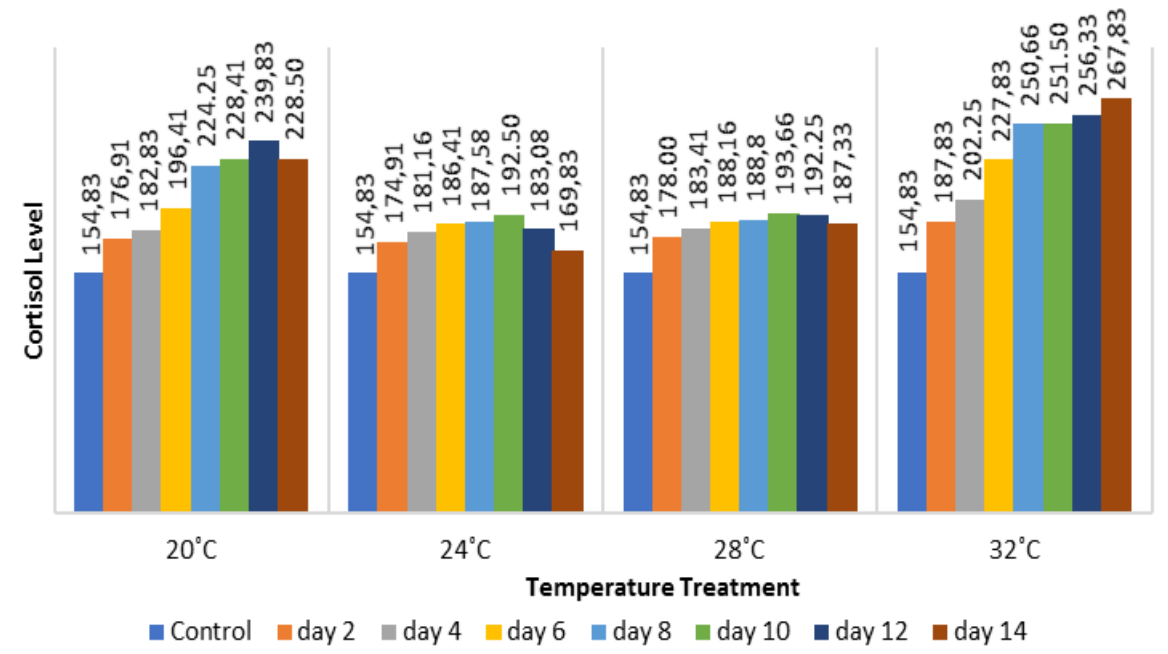

Figure 1. Cortisol Levels for 14 Days of Cultivation

Stressed fish will increase the secretion of catecholamines and cortisol [14]. Both hormones at high levels negatively affect the fish's immune system, because increased cortisol in plasma will inhibit the formation of interleukins I and II. As a result, fish will lose their immunity and are easily infected with pathogens, thus, can cause a high mortality rate. Furthermore, increased cortisol and glucose levels in plasma indicate that fish experience prolonged stress, which results in specific and non-specific immune reactions of fish decreasing [14].

Cortisol levels in the blood due to stress, will mobilize glucose from reserves stored by the body into the blood, so that glucose in the blood increases. High cortisol levels cause metabolic effects such as modulation of carbohydrate metabolism through gluconeogenesis, increased turnover protein, regulation of amino acid metabolism, ammonia production and increased lipolysis [15], thus increasing blood glucose. Fish will repeatedly have stressful situations and can show physiological responses such as accumulation of cortisol [16] which causes physiological conditions to decline, immunity decreases, even survival and growth of fish become threatened [17].

\section{Glucose}

Base on Figure 2, at a treatment temperature of $20^{\circ} \mathrm{C}$, changes in blood glucose levels continued to increase until they reached the highest peak on the $12^{\text {th }}$ day for $192.87 \mathrm{mg} \cdot \mathrm{L}^{-1}$ then decreased to $183.93 \mathrm{mg} \cdot \mathrm{L}^{-1}$. At $24^{\circ} \mathrm{C}$, the changes in glucose levels increased to the highest point on the $10^{\text {th }}$ day which was around 193.93 mg. $\mathrm{L}^{-1}$ and then continued to decline until the $14^{\text {th }}$ day, which was $165.27 \mathrm{mg} \cdot \mathrm{L}^{-1}$. At a temperature treatment of $28^{\circ} \mathrm{C}$, it was almost the same as the $24^{\circ} \mathrm{C}$ temperature treatment, i.e. blood glucose levels continued to increase from the first day of maintenance to reach the highest peak on the $10^{\text {th }}$ day, namely $202.60 \mathrm{mg} . \mathrm{L}^{-1}$, then a decline until the $14^{\text {th }}$ day, namely $182.13 \mathrm{mg} \cdot \mathrm{L}^{-1}$. However, at $32^{\circ} \mathrm{C}$, the blood glucose levels continued to increase until the $14^{\text {th }}$ day which was around $233.27 \mathrm{mg} . \mathrm{L}^{-1}$. It can be said that at a temperature of $32^{\circ} \mathrm{C}$, it is not suitable for the life of the Uceng fish due to the temperature range, fish stress continues to increase. In accordance with the results of a study, states that Tapah fish which are kept at $31^{\circ} \mathrm{C}$ produce increased blood glucose levels or hyperglycemia [18]. This condition reflects that the temperature of $31^{\circ} \mathrm{C}$ is not able to reduce stress or failure to achieve glucose homeostasis due to the occurrence of stress at very high levels [19].

Blood glucose levels that continue to increase indicate the flow of glucose into the blood that is greater than the entry of blood glucose into cells. Conversely, glucose levels will decrease if the flow of glucose into the blood is lower than entering blood glucose into cells. Thus, the peak blood glucose level occurs when the flow of glucose into the blood and the entry of blood glucose into the cell reach the point of balance [20].

Glucose that has entered the cell will be immediately metabolized to meet energy needs thus avoiding the use of a number of amino acids as a source of metabolic energy [21]. The availability of glucose in cells is used to meet the physiological needs of the body and energy needs, after fulfilling high glucose intake will stimulate the occurrence of glycogenesis and lipogenesis [22]. 


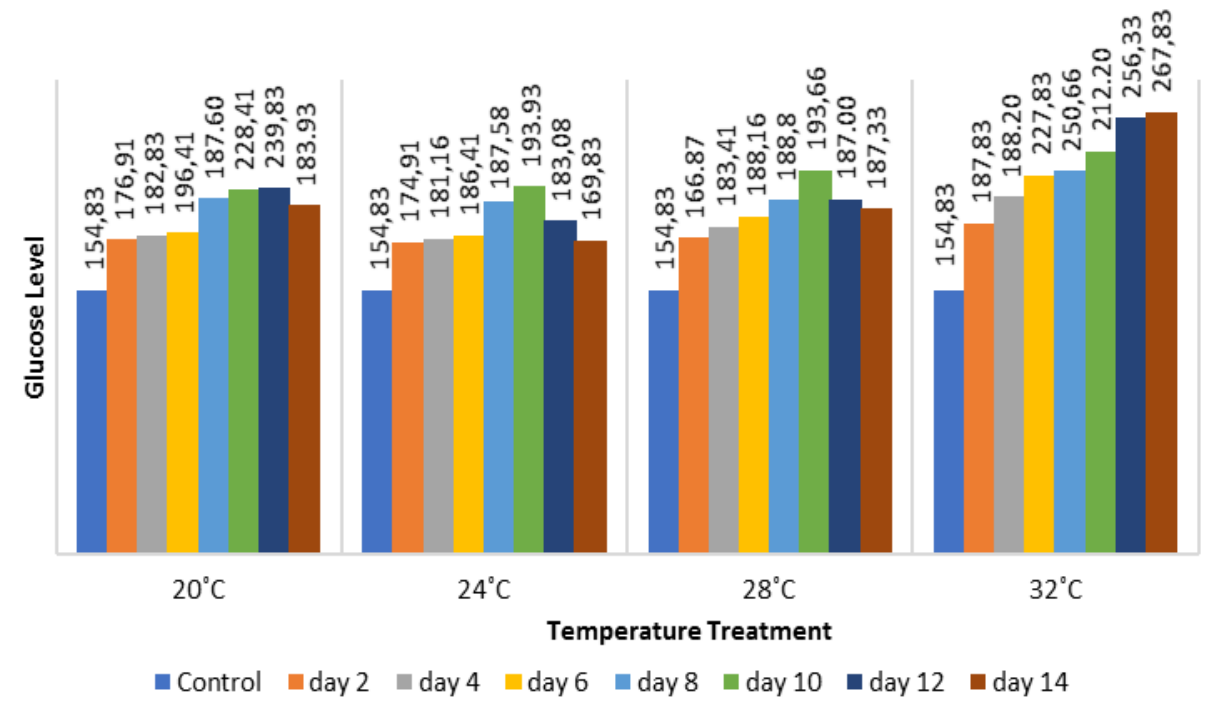

Figure 2. Glucose Levels for 14 Days of Cultivation

\section{Glycogen}

Base on Figure 3, at a temperature of $20^{\circ} \mathrm{C}$, changes in glycogen levels from the first day continued to increase until the $14^{\text {th }}$ day was $29.16 \mathrm{mg} \cdot \mathrm{g}^{-1}$. This is because fish do not experience prolonged stress so glycogen is not needed as an energy requirement. At $24^{\circ} \mathrm{C}$, the glycogen changes decreased on the $2^{\text {nd }}$ day (26.74 mg.g $\left.{ }^{-1}\right)$ until the $4^{\text {th }}$ day $\left(26.36 \mathrm{mg} \cdot \mathrm{g}^{-1}\right.$ ), then on the $6^{\text {th }}$ day $\left(29.17 \mathrm{mg} \cdot \mathrm{g}^{-1}\right)$ until the $12^{\text {th }}$ day (30.88) continued to increase. There was a decrease on the $14^{\text {th }}$ day which was $31.13 \mathrm{mg} \cdot \mathrm{g}^{-1}$. At a temperature treatment of $28^{\circ} \mathrm{C}$, it was almost the same as the treatment temperature of $24^{\circ} \mathrm{C}$, namely glycogen levels on the $2^{\text {nd }}$ day (26.69 mg.g $\left.\mathrm{g}^{-1}\right)$ until the $4^{\text {th }}$ day $\left(25.51 \mathrm{mg} \cdot \mathrm{g}^{-1}\right)$ decreased. Then on day $6\left(28.13 \mathrm{mg}^{-1} \mathrm{~g}^{-1}\right)$ until day $14\left(30.50 \mathrm{mg} . \mathrm{g}^{-1}\right)$ continued to increase. This is suspected, even though Uceng fish has an increase in blood glucose and cortisol, which is thought to be stressful, the fishes are still consuming a lot of feed given so that glycogen levels will increase.

An increase in glycogen levels indicates an excess of blood glucose after metabolic energy needs are met, which is immediately converted to glycogen and then stored in the muscles and liver [23]. Carbohydrates consumed by fish will be digested become glucose. At a temperature treatment of $32^{\circ} \mathrm{C}$ glycogen levels on day 2 (26.19 $\left.\mathrm{mg} \cdot \mathrm{g}^{-1}\right)$ until day 4 (25.50 $\left.\mathrm{mg} \cdot \mathrm{g}^{-1}\right)$ decreased because the fish has prolonged stress and took glycogen levels that had been stored previously. Then there was an increase until the $8^{\text {th }}$ day $\left(27.64 \mathrm{mg} \cdot \mathrm{g}^{-1}\right)$ then decreased again on the $12^{\text {th }}$ day $\left(26.85 \mathrm{mg}^{-1}\right.$ ) and increased again on the $14^{\text {th }}$ day which was $27.83 \mathrm{mg} \cdot \mathrm{g}^{-1}$.

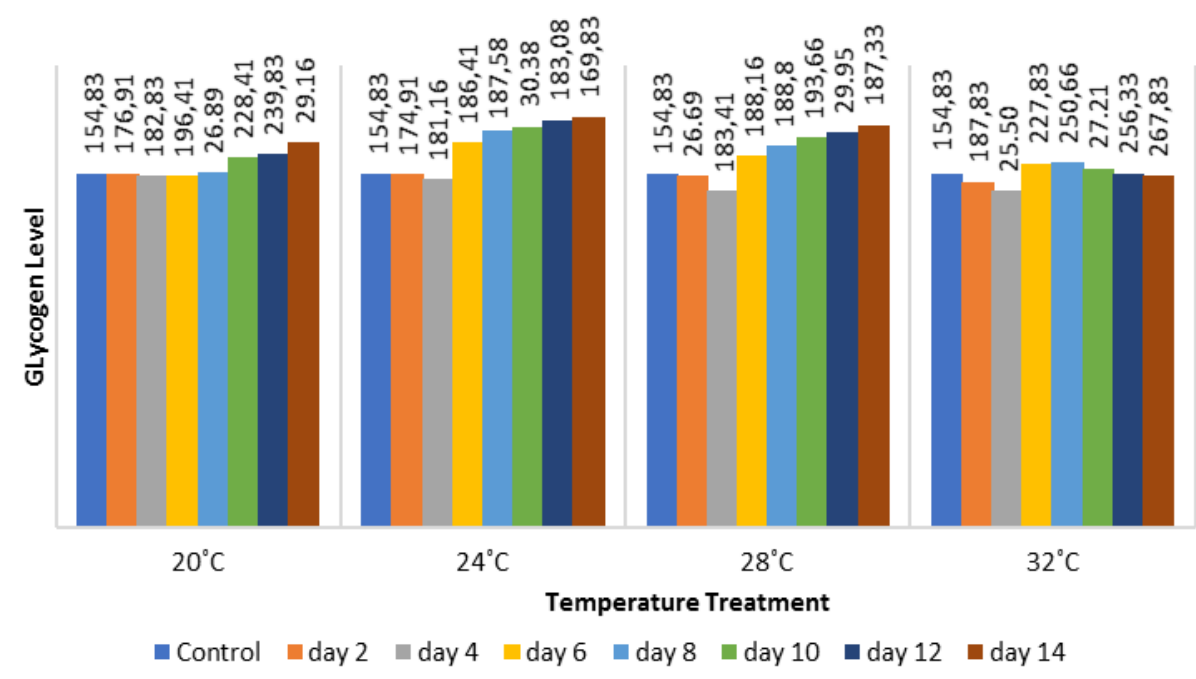

Figure 3. Glycogen Levels for 14 Days of Cultivation 
In freshwater, decreased glycogen levels can lead to the need for glucose as long as the fish experience stress, resulting in glycogenolysis activity, which is the breakdown of glycogen into glucose. In Oncorhynchus mykiss (Rainbow Trout), the highest glycogenolysis activity occurs in the liver, which is $60 \%$ compared to muscle organs and other organs [24]. Glycogen comes from excess glucose in the blood. Carbohydrates consumed by fish will be digested in the digestion to become glucose. Glucose will be absorbed by the intestinal wall and then transported in the blood. In the liver, glucose will enter the hepatocyte cells easily and then converted into glycogen [25].

Temperature greatly affects blood glucose levels but the pattern is inconsistent [26]. The Blood glucose level of fish rapidly increases within a short period after stress primarily due to the activation of hepatic $\beta$-adrenoceptors and glycogenolysis $[27,28]$. Fish subjected to stress challenges increase energy metabolism to cope with stress response, and glucose is used as the main energy fuel $[27,29]$. Glucose that enters the blood beside being used as a source of energy that is entering the citric acid cycle to produce energy, the excess will be stored in the form of glycogen and will be used as a source of energy through the process of glycogenicity after being converted back into blood glucose. Liver glycogen is strongly associated with hexose deposits and deliveries to maintain blood glucose levels, especially when between meals. After 12-18 hours of fasting, almost all of the liver's glycogen deposits were depleted. So that the glycogen content in the liver is related to the efficiency of digestion and absorption of glucose from the feed used. The liver glycogen content varies from each treatment combination.

The glycogen content that had accumulated will shrinkage. In the liver, glycogen degradation and synthesis play major roles in regulating blood glucose homeostasis and supplying energy to other tissues [30,31]. When environmental temperature decreased to $8^{\circ} \mathrm{C}$, however, the energy utilization strategy of sea bream changed to the production of nonpolar and polar lipids, whereas the glycogen content in the livers was not significantly changed. In environments with much lower temperatures, the production of lipids was altered to maintain membrane fluidity, and glycogen storage decreased in the liver of the sea bream [32,33].

\section{CONCLUSION}

Temperature affects the physiological response (cortisol, blood glucose, and glycogen) of Uceng fish (Nemacheilus fasciatus). High levels of cortisol and blood glucose indicate stressful fish.

\section{REFERENCES}

[1] Kottelat, M. 2012. Conspectus cobitidum*: an inventory of the loaches of the world (Teleostei: Cypriniformes: Cobitoidei). Raffless Bull. Zool. 26. 1-199.

[2] Hadiaty, R.A. 2014. Taxonomic study of the Genus Nemacheilus (Telestei : Nemacheilidae) in Indonesia. PhD Thesis. Graduate Scool of Engineering and Science University of the Ryuskyus. Taiwan.

[3] Prakoso, V.A., J. Subagja, A.H. Kristanto. 2017. Aspek biologi reproduksi dan pola pertumbuhan ikan Uceng (Nemacheilus fasciatus) dalam pemeliharaan di akuarium. Jurnal Media Akuakultur. 12(2). 67-74.

[4] Fajarwati, E.M. 2006. Studi mengenai aspek eko-biologi ikan Lalawak (Barbodes balleroides) pada berbagai ketinggian tempat di kabupaten Sumedang, Jawa Barat. Bachelor Thesis. Bogor Agricultural University. Bogor.

[5] Nofrizal, K. Yanase, T. Arimoto. 2009. Effect of temperatur on the swimming endurance and post-exercise recovery of jack macke-rel Trachurus japonicus as determined by monitoring. Fish Sci. 75. 1369-1375.

[6] Syawal, H., Y. Ikhwan. 2011. Respon fisiologis ikan Jambal Siam (Pangasius hipoptalamus) pada suhu pemeliharaan yang berbeda. Berkala Perikanan Trubuk. 39(1). 51-57.

[7] Masjudi, H., M.U. Tang, H. Syawal. 2016. Kajian tingkat stres ikan Tapah (Wallago leeri) yang dipelihara dengan pemberian pakan dan suhu yang berbeda. Berkala Perikanan Terubuk. 44(3). 69-83.

[8] Brown, J. A. 1993. Endocrine responses to environmental pollutions. In: Rankin, J.F., F.B. Jemsen (Eds). Fish Ecophysiology. Chapman \& Hall. London. 276-292.

[9] Guest, T.W., R.B. Blaylock, A.N. Evans. 2016. Development of a modified cortisol extraction procedure for intermediately sized fish not amenable to whole-body or plasma extraction methods. Fish Physiol. Biochem. 42(1). 1-6.

[10] Syawal, H., Y. Ikhwan. 2011. Respon fisiologis ikan Jambal Siam (Pangasius 
hipoptalamus) pada suhu pemeliharaan yang berbeda. Berkala Perikanan Trubuk. 39(1), 51-57.

[11] Velasco-Santamaría, Y., P. Cruz-Casallas. 2007. Methodology for determination of plasma cortisol in fish using competitive enzyme-linked immunosorbent assay (ELISA). Rev. MVZ Cordoba. 12(1). 869-877.

[12] Suarsana, I.N., B.P. Priosoeryanto, T. Wresdiyati, M. Bintang. 2010. Sintesis glikogen hati dan otot pada tikus diabetes yang diberi ekstrak tempe. Jurnal Veteriner. 11(3). 190-195.

[13] Elabscience. 2018. Glycogen assay kit. $8^{\text {th }}$ Ed. revised in February, 2018. Elabscience.

[14] Aslamyah, S. 2006. Penggunaan mikroflora saluran pencernaan sebagai probiotik untuk meningkatkan pertumbuhan dan kelangsungan hidup ikan Bandeng. PhD Thesis. Postgraduate School, Bogor Agricultural University. Bogor.

[15] Mommsen, T.P., M.M. Vijayan, T.W. Moon. 1999. Cortisol in teleosts: dynamics, mechanisms of action, and metabolic regulation. Rev. Fish Biol Fish. 9(3). 211-268.

[16] Koakoski, G., L.C. Kreutz, M. Fagundes, T.A. Oliveira, D. Ferreira, J.G.S. da Rosa, L.J.G. Barcellos. 2013. Repeated stressors do not provoke habituation or accumulation of the stress response in the catfish Rhamdia quelen. Neotrop. Ichthyol. 11(2). 453-457.

[17] Wedemeyer, G.A. 1996. Physiology of fish in intensive culture systems. Chapman and Hall.

[18] Suarez, M.D., A. Sanz, J. Bazoco, M.G. Gallego. 2002. Metabolic effects of changes in the dietary protein: carbohydrate ratio in eel (Angilla anguilla) and trout (Oncorhynchus mykiss). Aquac. Int. 10. 143156.

[19] Stryer, L. 2000. Biokimia. $4^{\text {th }}$ Ed. VoL. 2. EGC. Jakarta.

[20] Handayani, S. 2011. Uji toleransi glukosa dan uji toleransi insulin glukosa pada ikan Gurame yang diberi pakan mengandung kadar protein dan karbohidrat yang berbeda. Bogor Agricultural University. Bogor.

[21] Hadim, E., M.I. Djawad, M.Y. Karim. 2002. Kondisi glikogen dalam hati juvenil ikan Bandeng (Chanos Chanos Forskall) yang dibantut. Laboratory of Ecotoxicology and Physiology of Marine Biota, Hasanuddin University. Makassar.
[22] Adam, H.M. 2004. Comparative studies on the effect of water quality on haematological of Orechromis niloticus under culture condition. PhD. Thesis. Sudan University of Science and Technology.

[23] Svobodova, Z., B. Vykusova, H. Modra, J. Jarkovsky, M. Smutna. 2006. Haematological and biochemical profile of harvest-size carp during harvest and post-harvest stroge. Aquac. Res. 37. 959-965.

[24] Mehrani, H., K.B. Storey. 1993. Control of glycogenolysis and effects of exercise on phosphorylase kinase and CAMP-dependent protein kinase in rainbow trout organs. Biochem. Cell Biol. 71(11-12). 501-506.

[25] Junqueira, L.C., J. Carneiro. 1995. Histologi Dasar, $3^{\text {rd }}$ Ed. EGC. Jakarta.

[26] Ottolenghi, C., A.C. Puviani, D. Ricci, L. Brighenti, E. Morsiani. 1995. Comparative biochemistry and physiology part A: physiology. 111(2). 229-235.

[27] Wendelaar B.S.E. 1997. The stress response in fish. Physiol. Rev. 77. 591-625.

[28] Fabbri, E., A. Capuzzo, T.W. Moon. 1998. The role of circulating catecholamines in the regulation of fish metabolism: an over-view. Comp. Biochem. Physiol. C. 120. 177-192.

[29] Lupatsch, I., G.A. Santos, J.W. Schrama, J.A.J. Verreth. 2010. Effect of stocking density and feeding level on energy expenditure and stress responsiveness in European sea bass Dicentrarchus labrax. Aquaculture. 298. 245250.

[30] Vornanen, M., J. Haverinen. 2011. Seasonality of glycogen phosphorylase activity in crucian carp (Carassius carassius L.). J. Comp. Physiol. B. 181(7). 917-926.

[31] Polakof, S., S. Panserat, J.L. Soengas, T.W. Moon. 2012. Glucose metabolism in fish: a review. J. Comp. Physiol. B. 182(8). 10151045.

[32] Ibarz, A., J. Blasco, M.A. Gallardo, J. Fernández-Borràs. 2010. Energy reserves and metabolic status affect the acclimation of gilthead sea bream (Sparus aurata) to cold. Comp. Biochem. Physiol. A Mol. Integr. Physiol. 155(3).319-326.

[33] Melis, R., R. Sanna, A. Braca, E. Bonaglini, R. Cappuccinelli, H. Slawski, T. Roggio, S. Uzzau, R. Anedda. 2017. Molecular details on gilthead sea bream (Sparus aurata) sensitivity to low water temperatures from $<$ sup $>1<$ sup $>$ H NMR metabolomics. Comp. Biochem. Physiol. A Mol. Integr. Physiol. 204. 129-136. 